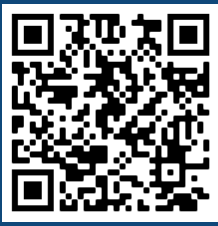

Keywords:

Water stress

llex paraguariensis

leaf production

Historic:

Received 17/04/2020

Accepted 10/07/2020

Correspondence:

fermingortari@facfor.unam.edu.ar
Fermin Gortari ${ }^{1 \mathrm{a}+}$, Walter Oscar Londero ${ }^{\mathrm{lb}}$, Patricia Rocha ${ }^{\mathrm{lc}}$, Fernando Niella ${ }^{\mathrm{ld}}$

\section{GROWTH AND PHYSIOLOGICAL RESPONSES OF YERBA MATE SEEDLINGS AND MINI-CUTTINGS UNDER DROUGHT STRESS}

GORTARI, F.; LONDERO, W. O.; ROCHA, P.; NIELLA, F. Growth and physiological responses of yerba mate seedlings and mini-cuttings under drought stress. CERNE, v. 26, n. 3, p.34I-348, 2020.

\section{HIGHLIGHTS}

Yerba mate seedlings and mini-cuttings showed similar response under drought.

Yerba mate plants had less accumulation of dry weight due to drought, mainly leaves.

Stressed yerba mate plants had fewer leaves, less foliar area, and chlorophyll content.

It is potentially safe to use mini-cuttings at commercial scale.

\section{ABSTRACT}

Yerba mate is a tree species whose natural distribution occurs in the countries of Argentina, Paraguay, and Brazil, where most of the plantations are concentrated. For the establishment of plantations seedlings are commonly used. But alternatively, there are ex vitro vegetative propagation techniques like mini-cuttings technology, which has the potential to facilitate plant production and increase the amount of plants needed for the industry. Yerba mate is sensitive to drought stress, negatively affecting the plantation productivity. Therefore, the objective of this work was to evaluate the growth and physiological responses of yerba mate seedlings and mini-cuttings to conditions of drought stress (field capacity, moderate drought, and severe drought). Total height, diameter at root collar, accumulation of dry weight (roots, leaves and stem), leaf number and area, and the content of chlorophylls were measured as response variables. Drought stress produced a decrease in height, dry wight accumulation, leaf number and area, and chlorophyll content, which was more pronounced in a situation of severe stress. The comparative analysis did not detect significant differences between seedlings and minicuttings, and there was also no interaction between the water restricted factors under consideration and type of propagule. 


\section{INTRODUCTION}

The yerba mate (llex paraguariensis St. Hil.) is a tree species whose natural distribution occurs in the interior Atlantic Forest ecosystem (Argentina, Paraguay and Brazil) (Gregianini and Winge, 20I9), and where most of the plantations are concentrated. In Argentina, the agroecological conditions for cultivation of this species include the provinces of Misiones and the northeast of Corrientes where a large production area of 160,000 ha exists to date (INYM, 2020). These plantations allowed the development of the entire agri-food chain for a market that is constantly growing and include the whole country and it is starting to grow in foreign markets as well. In Brazil, the plantations are in the southern states with 85,000 ha and in Paraguay in the western departments, with 35,000 ha. Commercial plantations of this species manage the tree as a hedge, harvesting the leaves annually, where the replacement time of the plants can be greater than 30 years (Eibl et al., 2000). These leaves are consumed as a traditional beverage (López et al., 2019).

One of the first steps in establishing $I$. paraguariensis plantations is the production of plants that will then be taken to the field. The highest proportion of propagules for yerba mate plantations are seedlings, produced by conventional nursery methods. However, given the low seed germination of the species and the need to increase the availability of selected material, the use of propagules obtained by asexual or vegetative propagation techniques known as mini-cuttings is being gradually adopted by farmers (Stuepp et al., 2017; Sá et al., 2018; Pimentel et al., 2019). Nevertheless, for mini-cuttings, the development of an adventitious roots system is critical and different from the seedlings ones (De Oliveira et al., 2019), being able among other factors, to affect the water absorption and consequently the response to water stress situation.

In general, plantations productivity is closely related to water availability (Álvares-Dávila et al., 2017; Jans et al., 2018). When trees are under drought stress situations, a decrease in stomatal conductance and photosynthetic activity occurs (Chen, 2020), resulting in a lower total dry weight, decrease in leaf area, loss of leaves or even total defoliation (Monclus et al., 2006). The yerba mate plant is very sensitive to drought stress, negatively affecting its growth and yield per hectare (Acevedo et al., 2016). This is because stomatal conductance and net photosynthesis are affected by drought stress situations (Acevedo et al., 2013; 2019) and can lead to decreases in leaf area and dry weight of plants (Sansberro et al., 2004).
There are no records for yerba mate where the behavior of plants is evaluated based on the type of propagule. However, for other tree species they do exist. In Eucalyptus globulus Labill. there were no differences in height growth in field trials among seedlings and minicuttings (Gaspar et al., 2005); also in Pinus taeda L., similar growths and vigor were observed between propagule types in the first 4 years after planting (Frampton et al., 2000). Moreover, the knowledge about the physiological response of yerba mate seedlings and mini-cuttings to drought stress has not been elucidated yet. To test the hypothesis that mini-cutting are more sensitive to drought stress than seedling due to its adventitious roots system, in this paper, a comparative whole plant analysis of seedlings and mini-cuttings subjected to drought stress, under controlled greenhouse conditions is presented.

\section{MATERIAL AND METHODS}

\section{Experiment location and plant material}

To carry out the proposed objective, a trial was conducted in the greenhouses of the Vegetative Propagation Laboratory, Faculty of Forest Sciences (FCF, UNaM, Misiones, Argentina). We worked with 3-monthold yerba mate plants in I-liter pots filled with composted pine bark and slow release fertilization (Plantacote ${ }^{\circledR}$ Plus $\left.6 \mathrm{M}, 3 \mathrm{~kg} \cdot \mathrm{m}^{-3}\right)$. To evaluate the effect of drought stress on the propagule type, seedlings $(\mathrm{S}$, from seeds and conventional nursery techniques of Vyo Nursery plants, Oberá, Misiones, Argentina) and mini-cuttings (M) obtained from ministumps (mother plants) were used, following Rocha et al. (2019) protocol. In both cases, the germplasm that gave rise to the seedlings and minicuttings was obtained from the polyclonal garden of the Cerro Azul Experimental Station (INTA, Misiones).

\section{Drought stress conditions}

All plants (with the same size at the beginning of the experiment) were kept with the substrate at field capacity until restricted irrigation treatments started (November I, 2018). We evaluated three water stress conditions: plants at field capacity (FC), substrate was always near field capacity when receiving a 10 second irrigation every half hour; moderate drought (DI), substrate was between 75 - 85\% of field capacity when receiving a 10 second irrigation every hour; and severe drought (D2), substrate was between 50 $-70 \%$ of field capacity when receiving a 10 second irrigation every two hours. The drought stress conditions of the substrate were carried out by drip irrigation controlled by programming in Arduino. Sensors were placed to control the soil moisture levels of treatments (Figure I). 


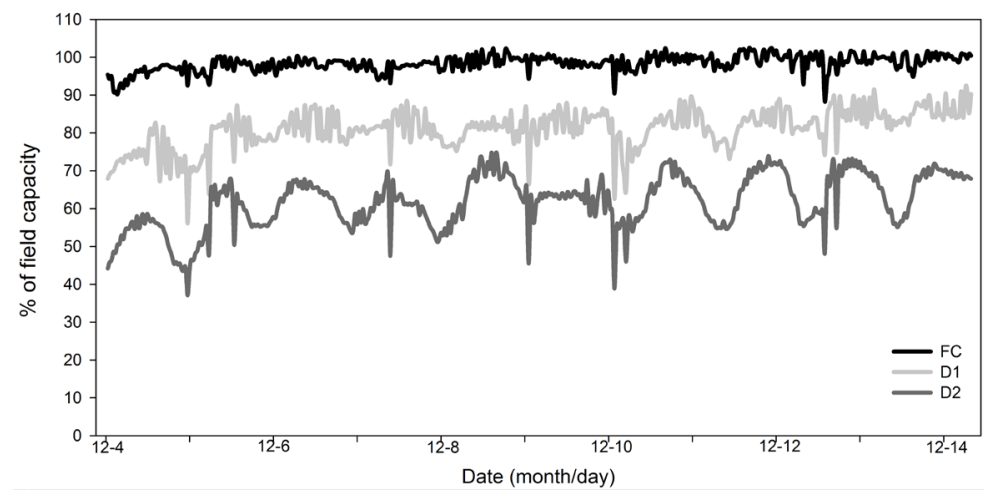

FIGURE I Record of substrate moisture content as percentage of field capacity for the different drought stress treatments. FC, plants at field capacity, DI, moderate drought; D2, severe drought.

\section{Greenhouse environmental conditions}

Since water status of the plants, also depends on the evaporative demand of the atmosphere, sensors for relative humidity and air temperature were placed to register and monitor daily variation inside greenhouse (Figures $2 \mathrm{~A}$ and $2 B$ ). Photosynthetic active radiation (PAR) conditions inside greenhouse were $50 \%$ of solar direct PAR, measurements were made with a Ceptometer (Cavadevices, Argentina) several days during the experiment.

\section{End of experiment and measurements}

Therefore, the experiment consisted of two factors: type of propagule ( $S$ and $M$ ) and drought stress (FC, DI and D2). It was terminated on December 20, 2018, where total height, diameter at root collar (CD), and number of leaves per plant were measured. The chlorophyll content of the first fully expanded leaf was measured with Chlorofilio ${ }^{\circledR}$ (Cavadevices, Argentina) and the leaf area per plant were determined by digital

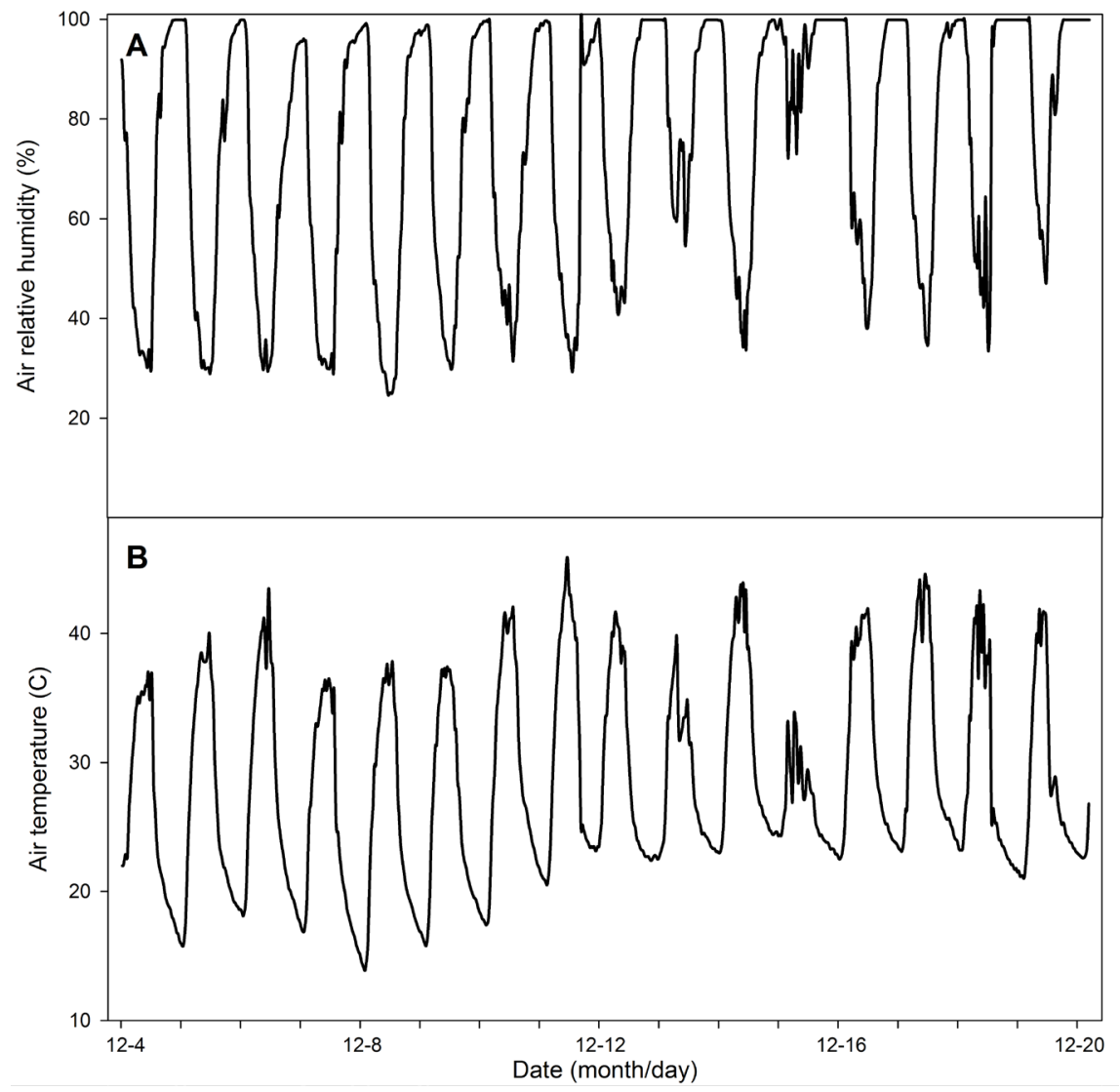

FIGURE 2 Record of air relative humidity (A) and temperature (B) during the last days of the experiment (from 12-4 to 12-20). The curves are the average values of the three sensors. 
photography and were analyzed using the CMEIASImageTool I.28 software.

For the determination of dry weight by compartments (stem, root and leaves), the roots were washed until all the substrate was removed and then they were placed in an oven at $60^{\circ} \mathrm{C}$, together with the stems and leaves until constant weight. Leaf dry weightroots dry weight (leaf DW-roots DW) and leaf DW-CD ratios were calculated.

\section{Statistical analysis}

A completely randomized design was used, with a factorial distribution of the treatments $(2 \times 3)$, two types of propagule $(\mathrm{S}, \mathrm{M})$ and three drought stress conditions (FC, DI and D2), with 5 replications per treatment, and plots of 5 plant per treatment, as the experimental unit. Data were analyzed using InfoStat Profesional software (Di Renzo et al., 2020). Once the normality and homogeneity requirements of the data deviations were carried out (Shapiro-Wilk test and Levene test respectively), the analysis of variance (ANOVA) was performed at the significance level of $5 \%(p<0.05)$. When ANOVA was significant, the Tukey test was used for the separation of means ( 3 or more levels).

\section{RESULTS}

$C D$ was not affected by stress, the type of propagule, or the interaction, presenting values between $6.64 \pm 0.16$ and $7.29 \pm 0.18 \mathrm{~mm}$ (Figure 3A). Height of the yerba mate plants was significantly affected when they were subjected to drought stress conditions, and by the type of propagule, but not by the interaction. Maximum height was presented by the FC treatment plants $(62.50 \pm 3.18 \mathrm{~cm})$ and the lowest height was for the D2 treatment plants $(53.27 \pm 2.43 \mathrm{~cm})$, while the DI treatment plants presented intermediate height values (Figure $3 \mathrm{~B}$ ). The $\mathrm{S}$ plants presented an average total height $(6 \mathrm{I} .22 \pm 2.88 \mathrm{~cm})$ comparatively higher than the M plants $(55.16 \pm 2.42 \mathrm{~cm}$ ) (Figure 3B).

Total dry weight of the plants was affected by drought stress $(p \leq 0.0 \mathrm{I})$, but not by the type of propagule $(p=0.27)$, nor for the interaction $(p=0.52)$. Plants that were at field capacity accumulated an average of $18.23 \pm$ $0.93 \mathrm{~g}$, differing significantly from the plants subjected to the $D I$ and $D 2$ treatments, with average values of $14.36 \pm$ 0.78 and $13.08 \pm 0.97 \mathrm{~g}$ per plants, respectively.

Analyzed by compartments, the accumulation of dry weight in stems and leaf compartments decreased significantly due to water stress treatment, but not for type of propagule or the interaction. Steam dry weight was 5.50 $\pm 0.43 \mathrm{~g}$ per plant in $\mathrm{FC}$ treatment and decrease to values of $4.40 \pm 0.22$ and $4.32 \pm 0.34 \mathrm{~g}$ per plant, for treatments DI and D2, respectively. The FC plants accumulated 8.56 $\pm 0.68 \mathrm{~g}$ per plant of dry weight in their leaves, while the plants from treatments DI and D2 accumulated 7.15 \pm 0.60 and $6.42 \pm 0.50 \mathrm{~g}$ per plants, respectively (Figure 4A and 4B). Root dry weight was not significantly affected by drought stress, propagule type, or interaction (Figure 4C).

There were no significant differences for leaves DW-roots DW ratio, due to the type of propagule, drought stress or interaction. Leaves DW-CD ratio was significantly affected by drought stress but not by the type of propagule, nor the interaction (Table I).

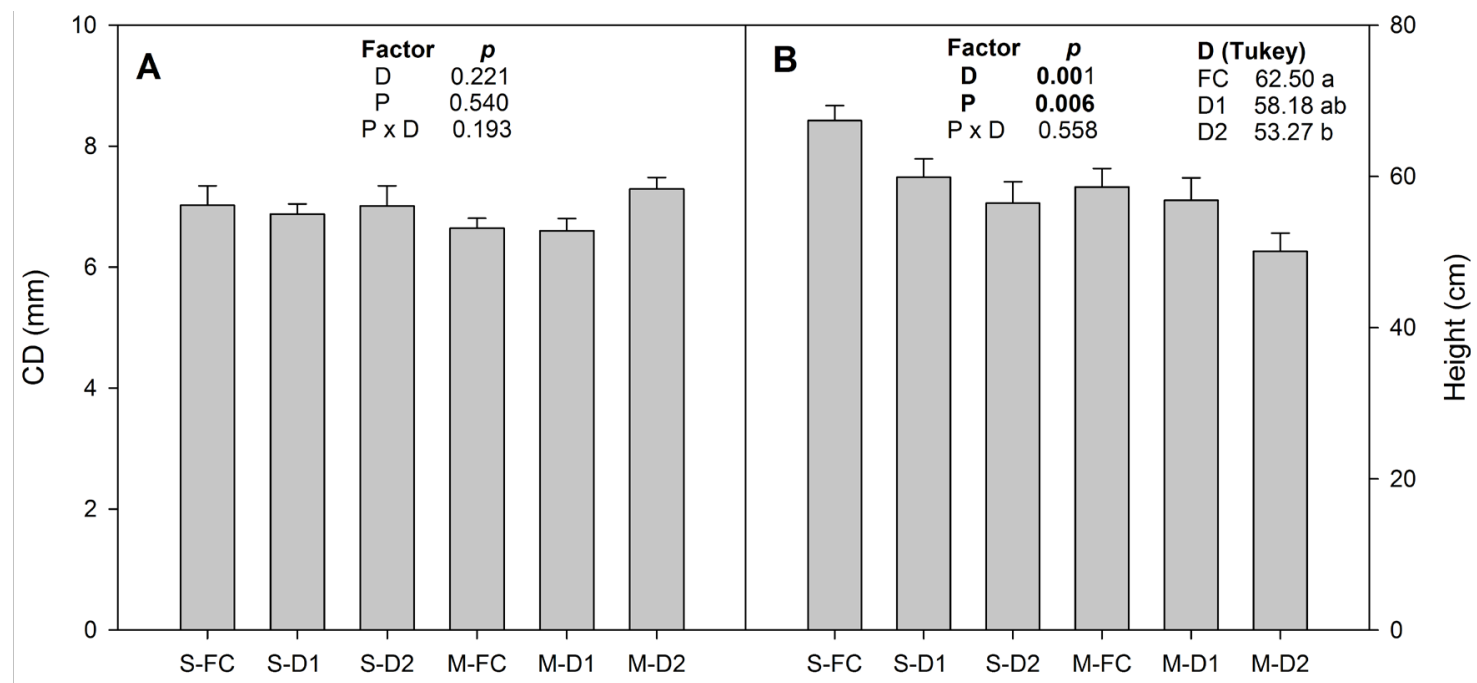

FIGURE 3 Diameter at root collar (CD, A) and height of the plants (B) for the different treatments. FC, plants at field capacity; DI, plant under moderate drought; $D 2$, plants under severe drought; $S$, seedling; $M$, mini-cuttings. The ANOVA and the $p$-values for each factor and the interaction are found in each panel, in bold indicates if there is significance $(p<0.05)$. Different letters mean differences between means by the Tukey test. 


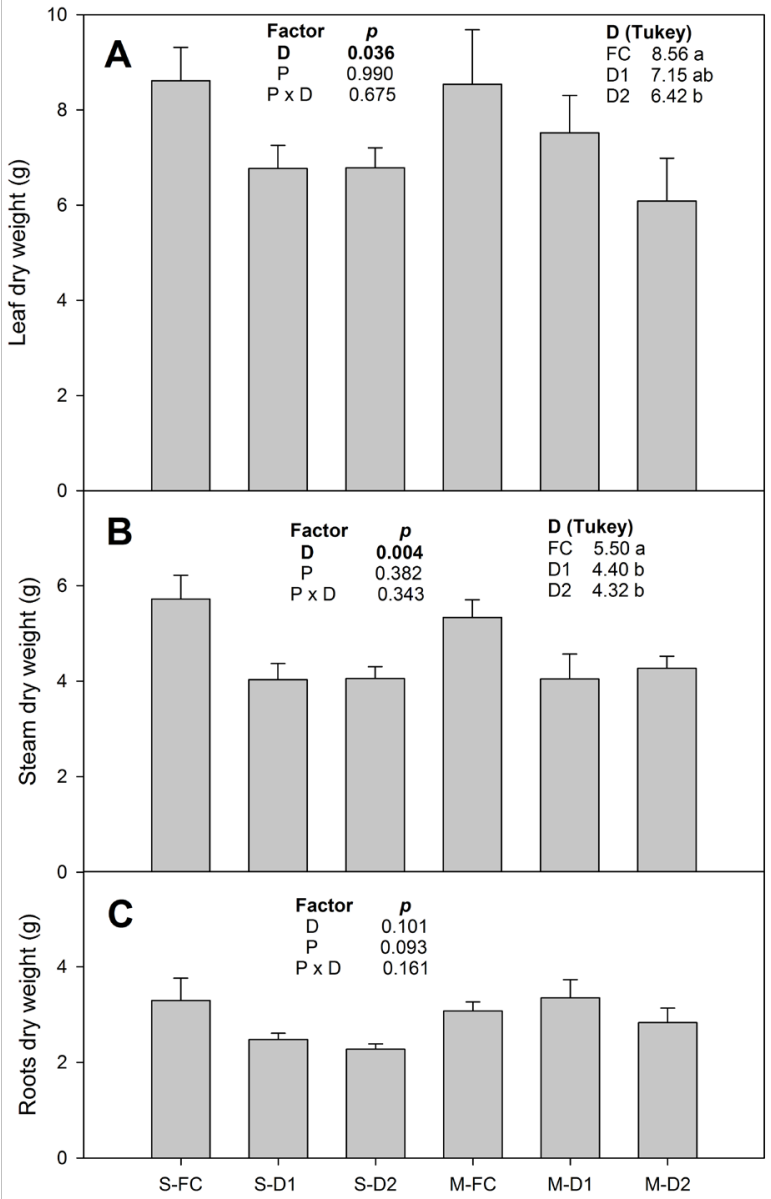

FIGURE 4 Leaf (A), stem (B) and roots (C) dry weight of the plants. FC, plants at field capacity; DI, plant under moderate drought; $D 2$, plants under severe drought; $S$, seedling; $M$, mini-cuttings. The ANOVA and the $p$-values for each factor and the interaction are found in each panel, in bold indicates if there is significance $(p<0.05)$. Different letters mean differences between means by the Tukey test.

TABLE I Leaf DW-CD and leaf DW-roots DW ratios. FC, plants at field capacity; DI, plant under moderate stress; $D 2$, plants under severe stress; $S$, seedlings; $M$, minicuttings. The ANOVA and the $p$-values for each factor and the interaction are found in the table, in bold if there is significance $(p<0.05)$. Different letters mean differences between means by the Tukey test.

\begin{tabular}{cccc}
\hline $\begin{array}{c}\text { Type of } \\
\text { propagules }\end{array}$ & Stress & Leaf DW- CD ratio & $\begin{array}{c}\text { Leaf DW -Roots DW } \\
\text { ratio }\end{array}$ \\
\hline \multirow{2}{*}{ S } & FC & I.2I $\pm 0.07 \mathrm{~A}$ & $2.79 \pm 0.33$ \\
& DI & $0.98 \pm 0.09 \mathrm{~B}$ & $3.04 \pm 0.32$ \\
& D2 & $0.97 \pm 0.08 \mathrm{~B}$ & $2.7 \mathrm{I} \pm 0.1 \mathrm{I}$ \\
& $\mathrm{FC}$ & $1.55 \pm 0.1 \mathrm{~A}$ & $3.09 \pm 0.37$ \\
M & $\mathrm{DI}$ & $0.94 \pm 0.22 \mathrm{~B}$ & $2.59 \pm 0.05$ \\
& $\mathrm{D} 2$ & $0.91 \pm 0.14 \mathrm{~B}$ & $2.42 \pm 0.20$ \\
\hline \multirow{2}{*}{ ANOVA } & $\mathrm{D}$ & $<0.0 \mathrm{I}$ & 0.53 \\
P-value & $\mathrm{P}$ & 0.45 & 0.53 \\
& $\mathrm{P} \times \mathrm{D}$ & 0.24 & 0.28 \\
\hline
\end{tabular}

Leaf number was affected by drought stress and by the type of propagule, but not by the interaction of the factors. Regarding stress factors, the FC and DI treatments presented $33.7 \mathrm{I} \pm \mathrm{I} .28$ and $33.1 \mathrm{I} \pm \mathrm{I} .57$ leaves respectively, differing from the D2 treatment where the average number of leaves was $28.44 \pm 1.98$. For the type of propagules, the $M$ treatment presented a greater number of leaves than the $S$ treatment, independently of the drought stress effect (Figure 5A).

Leaf area was affected by drought stress but not by the type of propagule or the interaction. The FC plants presented a leaf area of $998 \pm 100 \mathrm{~cm}^{2}$, differing significantly from the D2 plants, where the leaf area was $636 \pm 150 \mathrm{~cm}^{2}$; DI treatment plants presented intermediate values (Figure 5B).

Chlorophyll content, measured in SPAD units, was affected by drought stress but not for propagule type or by the interaction between factors. Plants $\mathrm{FC}$ and DI presented a SPAD value of $41.70 \pm 1.25$ and $41.50 \pm$ I. 35 respectively, differing from D2 plants with a value of $35.52 \pm 1.11$ (Figure 5C).

\section{DISCUSSION}

Vegetative propagation of yerba mate using the minicuttings technique, represents an opportunity to solve the limitations of seed propagation, such as low seed germination and variability in the offspring. However, it is important to highlight that the development of the root system obtained in both systems (by sexual and asexual reproduction) will be different (De Oliveira et al., 2019), so that the ability to respond to water stress situations might be altered.

I. paraguariensis plants are sensitive to water deficits, negatively affecting growth (height and biomass accumulation) because of a decreased photosynthetic capacity (lowers photosynthetic rate, chlorophyll content, stomatal conductance, leaf number and leaf area). During the annual growth cycle, plantations are subject to periods of water deficits and high temperatures in spring and summer, which negatively affect yields (Acevedo et al., 2016). In our experiment, the different type of plants tested (seedlings and mini-cuttings), showed a lower total height proportional to the stress level, being $7 \%$ and I $5 \%$ for plants subjected to drought stress in treatments DI and D2 respectively (Figure 3B). The same behavior was evidenced with more emphasis for the total dry weight of plants, with a decrease of 20 $\%$ and $28 \%$ in treatments DI and D2 respectively. A decrease in height and dry weight was observed for the clone "Garruchos 18" of I. paraguarinesis, in stressed plants compared to non-stressed plants. However, in this case, the water stress condition was not based on 


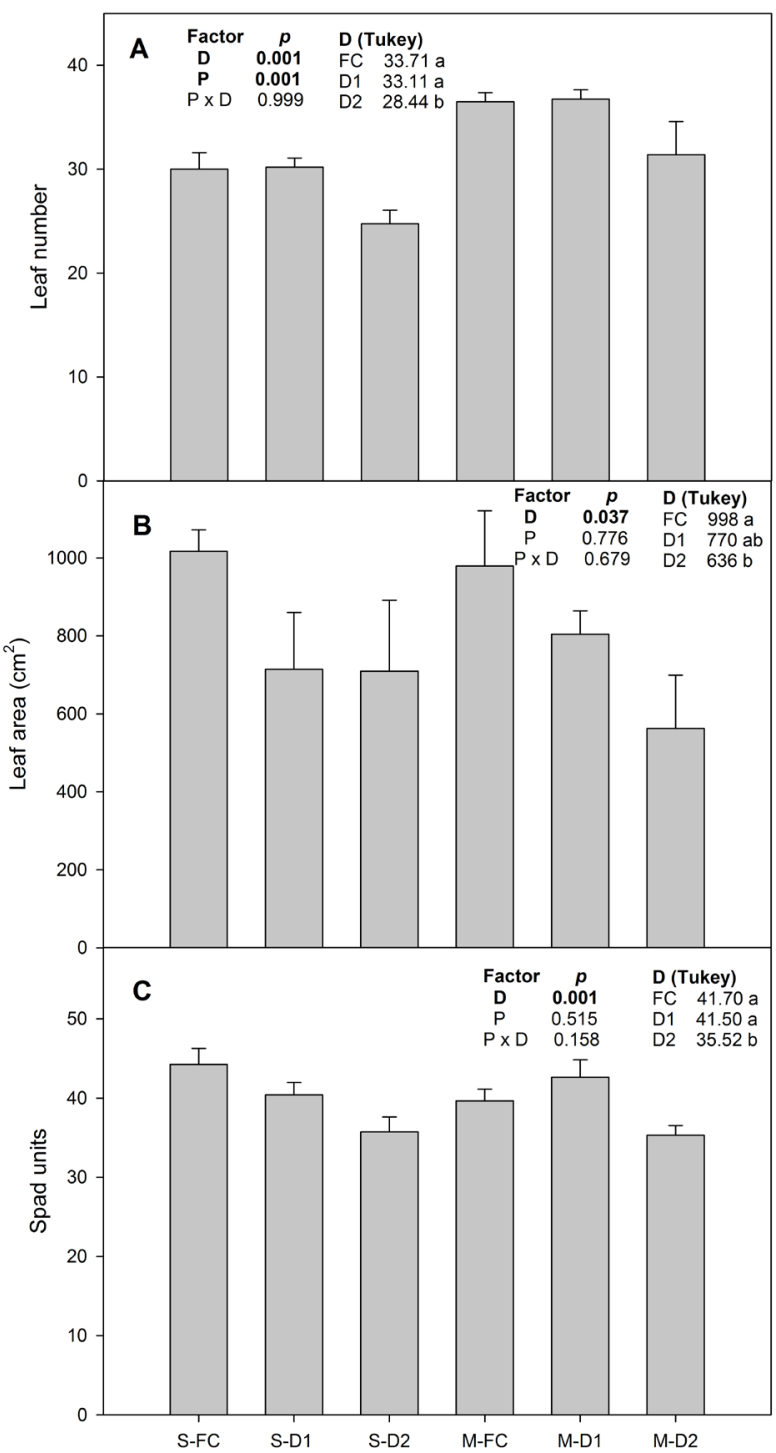

FIGURE 5 Leaf number (A), leaf area (B) and SPAD units (C) of the plants for the different treatments. FC, plants at field capacity; DI, plant under moderate drought; $D 2$, plants under severe drought; $S$, seedlings; $M$, mini-cuttings. The ANOVA and the p-values for each factor and the interaction are found in each panel, in bold indicates if there is significance $(p<$ 0.05 ). Different letters mean differences between means by the Tukey test.

water content of the substrate but depending on the evapotranspiration demand, limiting the loss of water from plants by transpiration, through the application of abscisic acid (Sansberro et al., 2004).

Nevertheless, the decrease in growth due to the lack of water in the soil profile, is widely proven for other tree species. Different origins of Eucalyptus sp. decrease the accumulation of dry weight, when comparing control plants with plants subjected to water stress; and the decrease is greater as the drought is more pronounced (Maseda and Fernández, 2016). In addition, in 29 genotypes of Populus deltoides W. Bartram ex Marshall $\times$ Populus nigra $L$. subjected to drought stress produced a decrease in plant height as well as dry weight accumulation (Monclus et al., 2006).

When analyzing the accumulation of dry weight by compartments, we observed that there were no differences in the accumulation of dry weight from roots, but there was a reduction for aboveground tissues of the yerba mate plants (leaves and stems) (Figure 4A, 4B and $4 C)$. Reduction in the accumulation of dry weight of leaves and stems was also observed in the clone "Garruchos 18" of $I$. paraguariensis, but in this case, the accumulation of dry weight of roots increased in stressed plants in relation to non-stressed plants (Acevedo et al., 2019).

These changes in the accumulation of dry wight are reflected in the changes in the relations between the aboveground and belowground tissues of the plants. In the present work, a decrease in the leaf DW-CD ratio was observed, when comparing non-stressed and drought stressed plants. However, for the leaf DW-roots DW ratio, there was a decrease in the ratio only for the mini-cuttings, although it was not statistically significant (Table I). Tree species tend to invest more carbon to the roots than to the aboveground tissues, at times of soil water deficits or excessive evapotranspiration demands, to optimize water uptake and limit water loss through transpiration (Brunner et al., 2015; Ledo et al., 2018). As an example, Cabralea canjerana (Vell.) Mart. plants have an aboveground/belowground biomass ratio close to 2 when the water conditions are favorable, while that ratio is less than 0.5 when the plants experience high evapotranspiration demands (Olguin et al., 2020).

The decrease in dry weight accumulation of leaves when the plants are stressed in relation to the nonstressed plants can be explained by a smaller number of leaves, a smaller leaf area per plant and a lower content of chlorophylls, being more notable in D2 plants (Figure $5 \mathrm{~A}, 5 \mathrm{~B}$ and $5 \mathrm{C}$ ). A decrease in dry weight accumulation associated with a decrease in leaf area was observed in yerba mate plants (Sansberro et al., 2004). At the same time, stressed yerba mate plants have a lower stomatal conductance and a lower net photosynthesis rate (Acevedo et al., 2013; 2019).

Although drought stress produced a reduction in height, accumulation of dry weight, number of leaves, leaf area and chlorophyll content in yerba mate plants; there was no interaction between drought and type of propagule for any of the variables analyzed. Both E. globulus seedlings and mini-cuttings, after 9 weeks subjected to drought stress, showed a decrease in height and stomatal conductance; but there was no interaction 
between the type of propagule and drought stress (Sasse and Sands, 1996). As we can see, similar physiological response of mini-cuttings and seedlings under water stress conditions are common in woody species.

\section{CONCLUSIONS}

Seedlings and mini-cuttings of $I$. paraguariensis subjected to different restricted irrigation levels (field capacity, moderate drought and severe drought), is a useful tool to evaluate the behavior of different types of propagules under drought stressed conditions, to be used for establishment of commercial plantations. Both type of plants showed the same response, that is, lower height, less accumulation of dry weight (mainly leaves), fewer leaves, less leaf area and chlorophyll content for water stressed levels tested compared to field capacity conditions. Hence, is potentially safe to use mini-cuttings at a commercial scale.

\section{REFERENCES}

ACEVEDO, R. M.; AVICO, E. H.; GONZÁLEZ, S.; SALVADOR, A. R.; RIVAROLA, M.; PANIEGO, N.; NUNES-NESI, A.; RUIZ, O.; SASBERRO, P. A. Transcript and metabolic adjustments triggered by drought in Ilex paraguariensis leaves. Planta, v. 250, n. 2, p. 445-462, 2019.

ACEVEDO, R. M.; RUIZ, O. A.; SANSBERRO, P. A. Gene expression changes in response to drought stress in llex paraguariensis leaves. Plant Omics Journal, v. 9, n. 5, p. 334-343, 2016.

ACEVEDO, R. M.; MAIALE, S. J.; PESSINO, S. C.; BOTTINI, R.; RUIZ, O. A.; SANSBERRO, P. A. A succinate dehydrogenase flavoprotein subunit-like transcript is upregulated in Ilex paraguariensis leaves in response to water deficit and abscisic acid. Plant Physiology and Biochemestry, v. 65, p. $48-54,2013$.

ÁLVAREZ-DÁVILA, E. A.; CAYUELA, L.; GONZÁLEZ-CARO, S.; ALDANA, A. M.; STEVENSON, P. R.; PHILLIPS, O.; COGOLLO, A.; PEÑUELA, M. C.; VON HILDEBRAND, P.; JIMÉNEZ, E.; MELO, O.; LONDOÑO-VEGA, A. C.; MENDOZA, I.; VELÁSQUEZ, O.; FERNÁNDEZ, F.; SERNA, M.; VELÁZQUEZ-RUA, C.; BENÍTEZ, D.; REY-BENAYAS, J.M. Forest biomass density across large climate gradients in northern South America is related to water availability but not with temperature. PLoS one, v. I2, n. 3, p. e0I7I072, 2017.

BRUNNER, I.; HERZOG, C.; DAWES, M. A.; AREND, M.; SPERISEN, C. How tree roots respond to drought. Frontiers in Plant Science, v. 6, n. 547, 2015.

CHEN, X.; ZHAO, P.; OUYANG, L.; ZHU, L.; NI, G.; SCHÄFER, K. V. R. Whole-plant water hydraulic integrity to predict drought-induced Eucalyptus urophylla mortality under drought stress. Forest Ecology and Management, v. 468, p. II8I79, 2020.
DE OLIVEIRA, T.P.; BARROSO, D. G.; FIGUEIREDO, F.; BARROS, T. C.; GAMBETTA, G. A.; CAMPOSTRINI, E. Gas exchange, root hydraulic conductivity, water use efficiency and the growth of Toona ciliata clones and seedlings. Ciência Florestal, v. 29, n. 2, p. 7I5-727, 2019.

DI RIENZO, J. A.; CASANOVES, F; BALZARINI, M. G.; GONZALEZ, L.; TABLADA, M.; ROBLEDO, C. W. InfoStat version 2017.I.2. Centro de Transferencia InfoStat, FCA, Universidad Nacional de Córdoba, Argentina. Available at: http://www.infostat.com.ar. Acceded in: June I0th 2020

EIBL, B.; FERNANDEZ, R. A.; KOZARIK, J. C.; LUPI, A.; MONTAGNINI, F.; NOZZI, D. Agroforestry systems with llex paraguariensis (American holly or yerba mate) and native timber trees on small farms in Misiones, Argentina. Agroforestry Systems, v. 48, n. I, p. I-8, 2000.

FRAMPTON, J.; LI, B.; GOLDFARB, B. Early field growth of loblolly pine rooted cuttings and seedlings. Souther Journal of Applied Forestry, v. 24, n. 2, p. 98- I05, 2000.

GASPAR, M. J.; BORRALHO, N.; LOPES GOMES, A. Comparison between field performance of cuttings and seedlings of Eucalyptus globulus. Annals of Forest Science, v. 62, n. 8, p. 837-84I, 2005.

Gregianini, T. S.; Winge, H. Storage protein variability in natural populations of maté (Ilex paraguariensis) in Brazil. Ciência Rural, v. 49, n. 2, p. e2018045I, 2019.

INYM, Available at: https://www.inym.org.ar/wp-content/ uploads/2017/02/sup_cultivada_dpto.pdf. Acceded in: April 10 2020.

JANS, Y.; BERNDES, G.; HEINKE, J.; LUCHT, W.; GERTEN, D. Biomass production in plantations: land constraints increase dependency on irrigation water. GCB Bioenergy, v. 10, p. 628-644, 2018.

LEDO, A.; PAUL, K. I.; BURSLEM, D. F. R. P.; EWEL, J. J.; BARTON, C.; BATTAGLIA, M.; BROOKBANKS, K.; CARTER, J.; EID, T. H.; ENGLAND, J. R.; FITZGERALD, A.; JONSON, J.; MENCUCCINI, M.; MONTAGU, K. D.; MONTERO, G.; MUGASHA, W. A.; PINKARD, E.; ROXBURGH, S.; RYAN, C. M.; RUIZ-PEINADO, R.; SOCHACKI, S.: SPECHT, A.; WILDY, D.; WIRTH, C.; ZERIHUM, A.; CHAVE, J. Tree size and climatic water deficit control root to shoot ratio in individual trees globally. New Phytologist, v. 217, n. I, p. 8-II, 2018.

LÓPEZ, A. C.; ALVARENGA, A. E.; ZAPATA, P. D.; LUNA, M. F.; VILLALBA, L. L. Trichoderma spp. from Misiones, Argentina: effective fungi to promote plant growth of the regional crop llex paraguariensis St. Hil. Mycology, v. I0, n. 4, p. $210-221,2019$

MASEDA, P. H.; FERNÁNDEZ, R. J. Growth potential limits drought morphological plasticity in seedlings from six Eucalyptus provenances. Tree Physiology, v. 36, n. 2, p. 243-25I, 2016

MONCLUS, R.; DREYER, E.; VILLAR, M.; DELMOTTE, F. M.; DELAY, D.; PETIT, J-M.; BARBAROUX, C.; LE THIEC, D.; BRECHET, C.; BRIGNOLAS, F. Impact of drought on productivity and water use efficiency in 29 genotypes of Populus deltoides $\times$ Populus nigra. New Phytologist, v. 169 , n. 4, p. 765-777, 2006. 
OLGUIN, F.Y; MORETTI, A. P.; PINAZO, M.; GORTARI, F; VERA BAHIMA, J., GRACIANO, C. Morphological and physiological plasticity in seedlings of Araucaria angustifolia and Cabralea canjerana is related to plant establishment performance in the rainforest. Forest Ecology and Management, v. 460, p. II 7867, 2020.

PIMENTEL, N.; LENCINA, K. H.; KIELSE, P.; RODRIGUES, M.; SOMAVILLA, T.; BISOGNIN, D. A. Produtividade de minicepas e enraizamento de miniestacas de clones de ervamate (Ilex paraguariensis A. St.-Hil.). Ciência Florestal, v. 29 , n. 2, p. 559-570, 2019.

ROCHA, P.; DUARTE, E.; GORTARI, F.; MORALES, V.; NIELLA, F. Protocolo para la propagación por minicepas y miniestacas de yerba mate (Ilex paraguariensis A. St. Hil.). Innovación y Desarrollo Tecnológico y Social, v. I, n. I, p. 6I-72, 2019.
SÁ, F.; PORTES, D.; WENDLING, I.; ZUFFELLATO-RIBAS, K. Minicutting technique of yerba mate in four seasons of the year. Ciência Florestal, v. 28, n. 4, p. |43I-|442, 2018.

SANSBERRO, P. A.; MROGINSKI, L. A.; BOTTINI, R. Foliar sprays with ABA promote growth of Ilex paraguariensis by alleviating diurnal water stress. Plant Growth Regulation, v. 42, n. 2, p. I05-I II, 2004.

SASSE, J.; SANDS, R. Comparative responses of cuttings and seedlings of Eucalyptus globulus to water stress. Tree Physiology, v. I6, n. I-2, p. 287-294, 1996.

STUEPP, C. A.; DE BITENCOURT, J.; WENDLING, I.; KOEHLER, H. S.; ZUFFELLATO-RIBAS, K. Age of stock plants, seasons and IBA effect on vegetative propagation of Ilex paraguariensis. Revista Árvore, v. 4I, n. 2, p. e4I0204, 2017. 